\title{
Ritualizar la muerte. Identidades latinoamericanas en las prácticas conceptuales de Alfredo Portillos
}

\author{
Juan Pablo Pérez \\ Universidad de Buenos Aires \\ Universidad Nacional del Arte \\ Universidad Nacional de Tres de Febrero \\ Centro Cultural de la Cooperación Floreal Gorini
}

Se trata en el arte de una confesión que esté a la altura de una conjuración mágica, que se elabora con terror y en la que se vuelca todo lo que se es.

Rodolfo Kusch

El presente trabajo consiste en articular ciertas continuidades estéticas entre las obras de Alfredo Portillos ${ }^{1}$ de los años setenta, que tiene como hilo conductor su instalación "Cementerio para los guerrilleros Latinoamericanos" de 1974 con el Grupo CAyC, y sus alternancias y limitaciones delineadas en los años

${ }^{1}$ Alfredo Portillos (1928-2017) recientemente fallecido, fue un artista que desde los años sesenta trabajó con lenguajes experimentales, lúdicos, geométricos y concretos, hasta que en los primeros años setenta inicia una labor más conceptual -en clave de sistemas de comunicaciónque va a derivar en la incorporación al arte de las prácticas rituales y religiones populares de América Latina como experiencias estéticas, performances y otros saberes que marcaron un sendero propio en la búsqueda y problematización de las identidades. 
noventa, analogías sincrónicas que permiten reflexionar en la espesura del debate sobre los "latinoamericanismos" el carácter colectivo, político y socialmente estético de las prácticas artísticas contemporáneas.

Nuestra hipótesis propone indagar sobre los resortes visuales que el artista se apoderó del campo religioso popular, trasladando las condiciones de materialidad que le permitieron alcanzar una estética singular y simbólica a través de la utilización de objetos precarios y marginales apropiados de los diferentes rituales y ceremonias que resignificarían ideológicamente la idea de muerte y memoria social en las obras de los años cincuenta y setenta como consolidación de un discurso estético latinoamericanista reactivado a partir de ciertas consideraciones del pensamiento "indoamericano" de Francisco René Santucho.

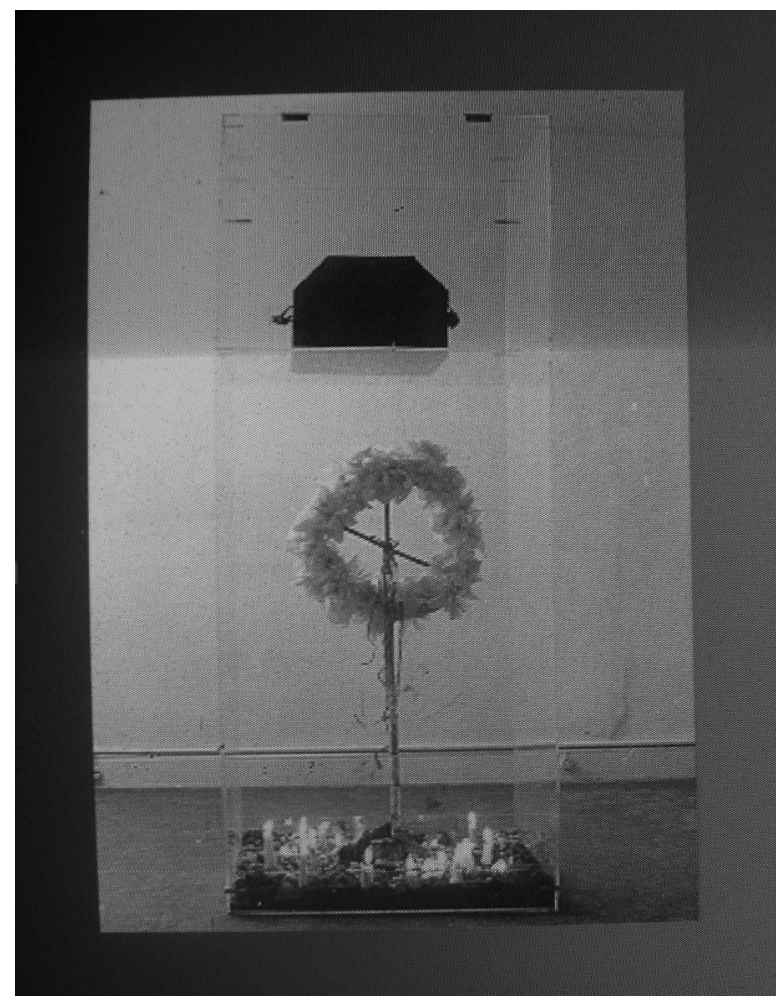

[Fig. 1. Alfredo Portillos, "Urna Funeraria de los Caídos por la Liberación Latinoamericana", 1973.]

Para el año 1973 se presentó la Cuarta Edición del Salón auspiciado por la empresa Acrílicospaolini. En esta entrega Alfredo Portillos realizó una obra haciendo uso del material acrílico brindado por la institución. Construyó una 
ermita transparente donde depositó en la parte superior un pequeño cajón de madera o urna funeraria. En el interior del cubículo, y de manera vertical a lo largo del prisma de acrílico, ordena y estructura la obra una cruz sepulcral con una corona de papel crepe blanco. La cruz opera en diálogo entre la urna funeraria y la base de la ermita que contiene tierra con algunas velas alrededor de la misma. En la lista de obras que aparecían en el catálogo, la pieza del artista llevaba por título "Urna Funeraria de los Caídos por la Liberación Latinoamericana".

El proceso de politización que vive el arte a principios de los años setenta envuelve a varias de las producciones de los artistas convocados en torno al Centro de Arte y Comunicación (CAyC). Tales propuestas casi no concebían el arte sin la reflexión política. En este sentido, observamos nuevos desarrollos formales y plásticos cuyas innovaciones trababan un diálogo innegable con el entorno político imperante.

En nuestro análisis, cabe señalar la aproximación conceptual de la urna funeraria que viene a anticipar el lugar que ocuparán las tumbas anónimas en el "Cementerio de los guerrilleros Latinoamericanos" de los años posteriores.

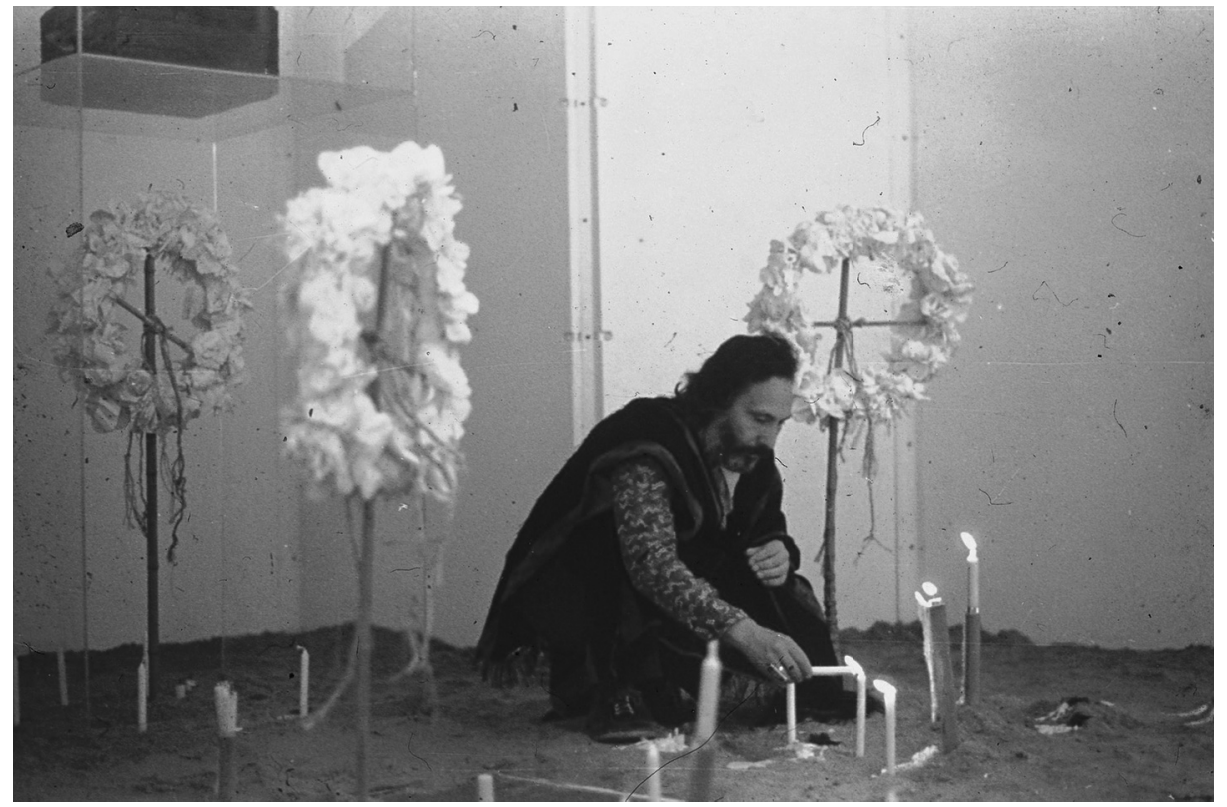

[Fig. 2. Alfredo Portillos, "Cementerio de los guerrilleros Latinoamericanos", 1974.]

Esta evocación alcanzaba de manera conmemorativa al pasado reciente $-\mathrm{y}$ anticipatorio al mismo tiempo- de los caídos que lucharon durante el proceso 
de liberación latinoamericana. Su imagen le permitía ahondar en la huella de la tradición visual de los santuarios populares, y conferirle cierta devoción absorbida de un imaginario que lo acercaba mucho más a lo rural, al mundo campesino, y por ende, a la cultura indoamericana.

Alrededor del año 1955, viviendo en la provincia de Tucumán (Argentina) $)^{2}$, Alfredo Portillos viajó a Santiago del Estero con su hermano para realizar una obra de títeres que luego retomaría en el teatro de las máscaras. En esa ciudad conoció en el espacio cultural de la librería "Aymará", luego llamada "Dimensión”, a Francisco René Santucho, intelectual que aglutinó las ideas del Frente Revolucionario Indoamericano Popular (FRIP) que reivindicaba la lengua de los pueblos originarios de América.

Para esos años Portillos estaba realizando unas pequeñas pinturas, que remiten a una serie de óleos muy sencillos, que abrazan imágenes casi de bocetos donde puede percibirse una mirada cotidiana, de paisajes de provincias, locales, en la que incluimos "Velorio" de $1954 .{ }^{4}$

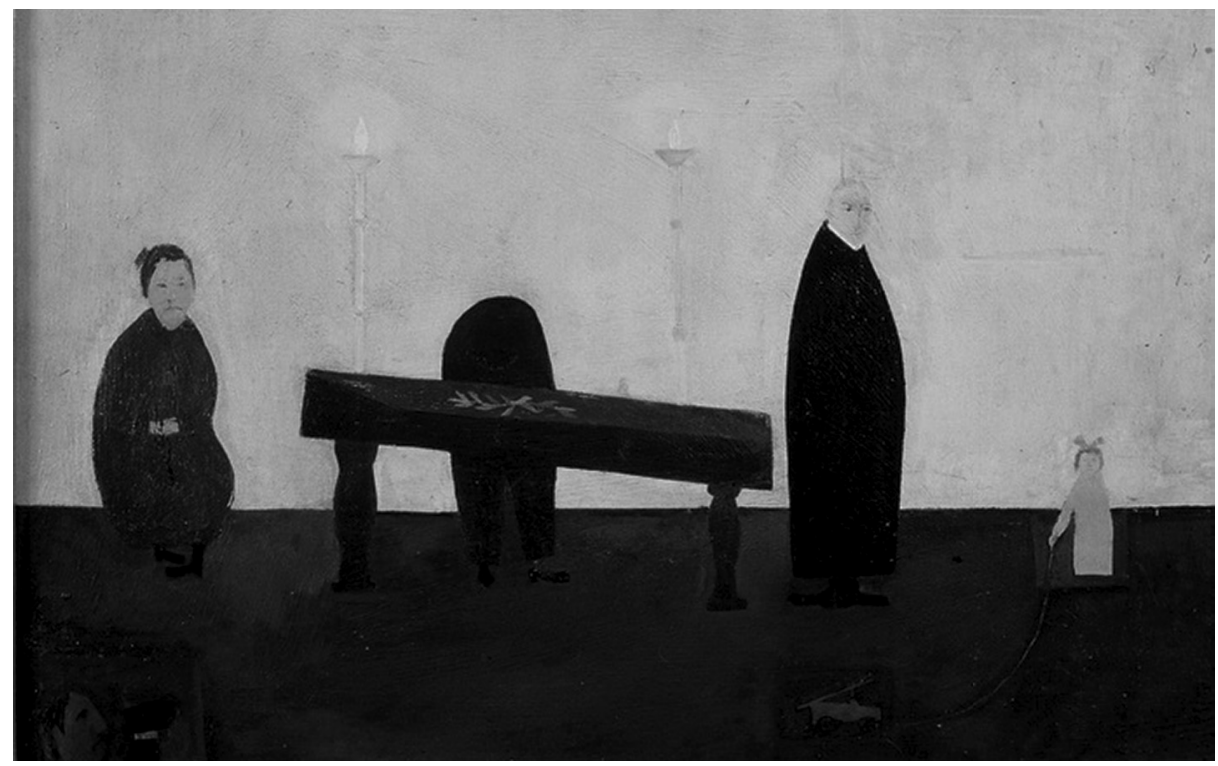

[Fig. 3. Alfredo Portillos, "Velorio", 1954.]

${ }^{2}$ En Tucumán estudió en el Taller de Lino Eneas Spilimbergo que dictaba en el Instituto de Arte de la Universidad Nacional de Tucumán.

${ }^{3}$ Para el año 1954 ya aparece editado por la Librería Aymará el libro de Francisco René Santucho El indio en la Provincia de Santiago del Estero. En un principio, la Librería fue fundada por Francisco René Santucho en 1952 con el nombre de "Aymara”. Posteriormente, a partir de 1957 asume el nombre de Librería Dimensión como la revista.

${ }^{4}$ Óleo sobre tela. 35 x 50 cm., 1954. Colección del Artista. 
Podemos visualizar un ataúd dispuesto con dos candelabros en un ámbito privado y la figura de la llorona que abre la atención de la mirada perdiendo la centralidad de la composición. La tensión creada por la postura del cura y el personaje inclinado sobre el cajón, envuelve a los personajes en una atmósfera de tonos bajos, negros y verde oliva, cuyas notas de color recaen en la pared del fondo iluminada como un halo sagrado por los velones.

Tratar el vínculo con la muerte como problemática cotidiana permite organizar un discurso visual al transitar una mirada local en un escenario de modernización suburbana. La figura de la niña con su vestido rosa provoca con su desolada presencia una desazón visual quitando todo sentido trágico, denso y lógico a la escena en una atmósfera metafísica, reflexiva, de tensa ambigüedad. La representación de la niña corresponde también a la tradición de la muerte como ceremonia pública, la cual era presenciada por parientes, familiares y amigos, y como menciona Philippe Ariès, no existe imagen de habitación de difunto sin la presencia de algunos niños. ${ }^{5}$

En diálogo con las pinturas de la etapa tucumana nace su inquietud por las culturas indígenas del lugar. Un antecedente claro del "pensamiento indoamericanista" fueron las reflexiones que para el año $1924^{6}$ elaboró incipientemente José Carlos Mariátegui 7 y luego de 1961, dicha categoría se reinstala en la lucha social y nacional por los hermanos Santucho desde el FRIP.

La identificación de Francisco René Santucho con dicho término provino de la generalización utilizada por el Aprismo peruano ${ }^{8}$, que definía una peculiar manera de reivindicar el indigenismo de la época:

Hoy podemos decir que ese sentimiento (Indoamericano) se ha renovado; la sensibilidad continental, la identidad continental, ha fructificado [...] en conciencia, en convicción. Para que ello haya sido posible fue necesario entre otras cosas, una intensa labor de tipificación engendrada en toda la extensión indoamericana [...] en esta percepción diferencial de América, está el sentido de su unidad y de su totalidad. ${ }^{9}$

5 ARIÈs 2007: 27.

${ }^{6}$ MARiátegui 1972 [1924]: 249.

7 "No queremos, ciertamente, que el socialismo sea en América calco y copia. Debe ser creación heroica. Tenemos que dar vida, con nuestra propia realidad, en nuestro propio lenguaje, al socialismo indo-americano. He aquí una misión digna de una generación nueva. Con esta misma preocupación en su libro Temas de Nuestra América”, Mariátegui se pregunta si: ¿Existe un pensamiento característicamente hispano-americano? MARIáTEGUI 1972 [1924].

${ }^{8}$ De SANTis 2006: 13-14. El APRA (Alianza Popular Revolucionaria Americana) peruano de Haya de la Torre fue inspirador del pensamiento indoamericano de Francisco René Santucho, al igual que la figura de Hugo Blanco cómo líder de los Sindicatos Campesinos armados del Departamento de Cuzco, quien había militado en "Palabra Obrera" a finales de los años cincuenta.

9 Santucho 1956. 
En las páginas de la Revista Dimensión que el "Negro" Santucho dirigió en Santiago del Estero entre 1956 y 1962, buscó dar cuenta de un itinerario teórico que condensara en su propio contexto el legado emancipatorio y la unicidad de la identidad indoamericana de todos los pueblos marginados de América. En su escrito de "América como conciencia" reinstala en sentido crítico la posibilidad de entender ciertas condiciones recurrentes que mantienen en común nuestra identidad, sin perder el grado de heterogeneidad constitutiva de las diferencias.

La importancia que adquiere el pensamiento de Francisco Santucho desde un espacio descentrado, marginado, en esos pocos números de la Revista Dimensión, pero elocuente en su propio contexto socio-histórico, resulta clave puesto que la densidad teórica de aquellos escritos de finales de la década del cincuenta no sólo gravitaron en los años posteriores en la praxis política y revolucionaria del FRIP y posteriormente del Partido Revolucionario de los Trabajadores-Ejército Revolucionario del Pueblo (PRT-ERP), sino que además, formó parte del sustento discursivo para pensar en los años setenta las claves históricas de la unidad de América Latina.

La referencia a lo indoamericano amplía el interés y la potencialidad artística de Portillos, que dentro de los espacios de la cultura visual, sobredimensiona el rescate del idealismo estético a partir de los rituales y cultos populares como un aporte sustancial a la construcción conceptual sobre las identidades del continente.

Para el año 1974, Portillos realiza la instalación "Cementerio de guerrilleros latinoamericanos" en la muestra colectiva con el Grupo de los Trece $(\mathrm{CAyC})$ en el Internationaal Cultureel Centrum de Amberes (Bélgica). ${ }^{10}$ En esa ocasión utilizó por segunda vez la ermita de acrílico con la urna funeraria de madera presentada en el Salón de Artistas con Acrílicospaolini de 1973, y alrededor de ella organizó un círculo de tierra al que sumo en ese mismo espacio estético instalado, otras cruces torcidas de cañas de tacuara, con coronas y velas. En este Cementerio Portillos realizó una performance cuya operación consistía en ir encendiendo cada una de las velas del espacio sacrosanto representado.

Si para el artista el Cementerio hacía alusión a los campos santos o enterramiento durante el período de la conquista y colonización, resulta interesante

${ }^{10}$ Al lado de una imagen del altar o cementerio latinoamericano dice: Homage to the fallen in the struggle for Latin American liberation (Northern Argentine tradition). "Alguien que ha conservado la memoria del pasado de su país es Alfredo Portillos. En el centro de su "Cementerio de guerrilleros Latinoamericanos" fue ubicada una espléndida y significativa urna. El clima turbulento que vive esa parte del mundo ha influenciado muchas de las obras, pero en una forma algo velada, y por lo menos para nosotros, no lo suficientemente fuerte. La prensa y publicaciones ilegales nos familiarizaron con otras situaciones de la que han querido informarnos los artistas". 
indagar sobre la resignificación que adquiere en su propio contexto político la propuesta de un cementerio para guerrilleros, por la cual un año antes, la misma urna funeraria simbolizaba el lugar de los caídos como héroes y el sacrificio en la lucha por la liberación latinoamericana.

A partir de 1974 Alfredo Portillos organizó una serie de pequeños dibujos esquemáticos que denominó "Dibujos Antropológicos"11, que básicamente tenían que ver con aproximarse a ciertos esquemas proyectuales de las instalaciones realizadas en esos años.

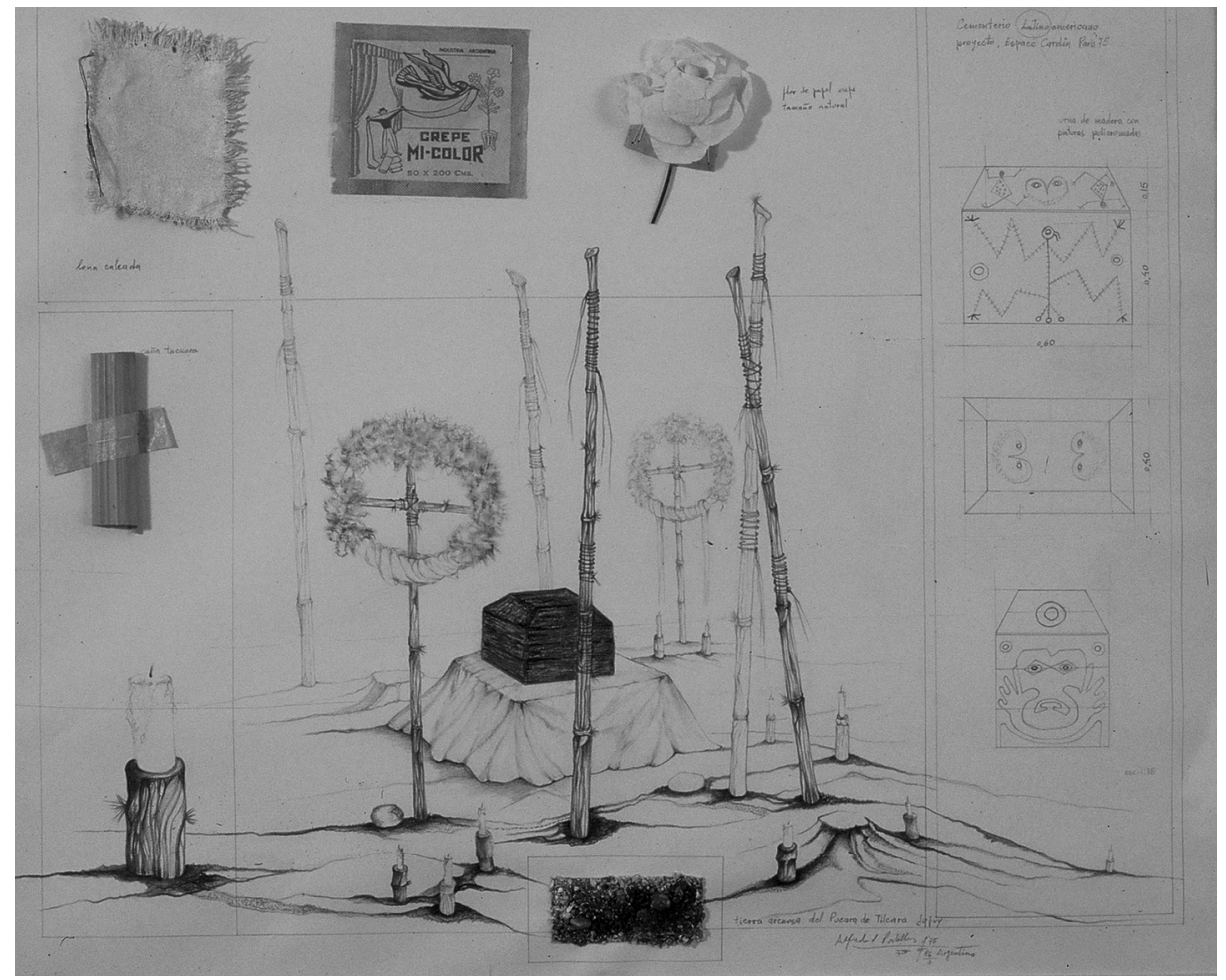

[Fig. 4. Alfredo Portillos, "Cementerio Latinoamericano". Espacio Pierre Cardin, París, 1975. Serie "Dibujos Antropológicos", 1975-1986.]

Figuran los altares y cementerios dibujados ordenadamente con grafito, de forma sutil, en combinación con fragmentos de las cañas de tacuara, pedacitos o recortes de tejidos, tierras de colores, algunas indicaciones sobre el origen de los objetos, comentarios y definiciones del título de las obras. Estos diseños

${ }^{11}$ La serie de dibujos aparecen firmados con doble fecha de concepción y realización entre los años setenta y noventa, evidenciando cierta continuidad en el discurso teórico de sus obras, aunque en cada período se modifique el aspecto formal. 
organizaban un proceso de concientización y decodificación gráfica de sus imágenes, que podrían entenderse como un momento de definición y confirmación de los límites de un lenguaje propio, que marcó su propuesta estética. Así como también, se evidenciaron las contradicciones, avales y rupturas institucionales, teniendo en cuenta que a finales de los setenta Jorge Glusberg -director del $\mathrm{CAyC}^{12}$ - cambió su línea de trabajo en excelentes relaciones con la dictadura a raíz de la promoción oficial que recibían sus exhibiciones. ${ }^{13}$

En el dibujo que retoma la urna funeraria, llevado adelante como trabajo de diseño, existe una especificación muy detallada de los elementos que componen la obra. Dos pequeños gráficos de urnas con iconografía precolombina y referencias sobre su utilización por los habitantes del noroeste argentino, tierra arenosa del Pucará del Tilcara (Sitio arqueológico prehispánico en la Provincia de Jujuy - Argentina), además de la fotografía de las velas y el boceto del fragmento de caña de tacuara, lana de llama o vicuña y flores de papel crepe. Concluye el esquema de este trabajo con la consigna ahora conmemorativa y simbólica de la lucha heroica: "Proyecto de monumento a los caídos en la liberación latinoamericana".

Estos dibujos antropológicos conceptualizaron las ideas centrales en la producción de Portillos, y funcionaron de alguna manera, como mediación con las obras que marcaron con mayor fuerza los trabajos de los últimos años de la década.

Algunos determinismos de la obra de Alfredo Portillos son plausibles en cuanto que suscitan en una primera instancia, una imagen directa que liga lo latinoamericano como idea esencialista en torno a los cementerios y altares religiosos populares, unificados por las diferentes producciones a lo largo del continente y bajo un mismo bloque cultural. Sin embargo, una segunda lectura más profunda, hecha desde el lenguaje abordado por el artista, podría ser pensada como una distinción local en clave conceptual -o hasta regional en algunos casos-, a partir de las condiciones materiales y formales desplegadas en la obra.

Lejos de cualquier tipología académica, su obra se acerca con una imagen singular a otro tipo de accionar visual. Las coronas de papel y de plásticos son encontradas y apropiadas de sus sitios originales, por lo general, en diferentes zonas del noroeste argentino cuyos objetos son recurrentes en las imágenes de sus altares y cementerios latinoamericanos. Restablecer la energía que poseen algunos de los símbolos visuales utilizados por Portillos envuelve la

${ }^{12}$ Las omisiones evidentes en dichas lecturas de la realidad universal (nacional) resultaron claras a partir de 1976, como por ejemplo, con el telegrama del presidente general Videla, que lo felicitaba por haber ganado en 1977 el premio de la XIV Bienal de San Pablo, al que contestó comprometiéndose ante él a "representar el humanismo del arte argentino en el exterior".

13 García Canclini 2001: 103. 
posibilidad de desarrollar empíricamente la carga de fuerza real que ofrece la tierra como materia de culto.

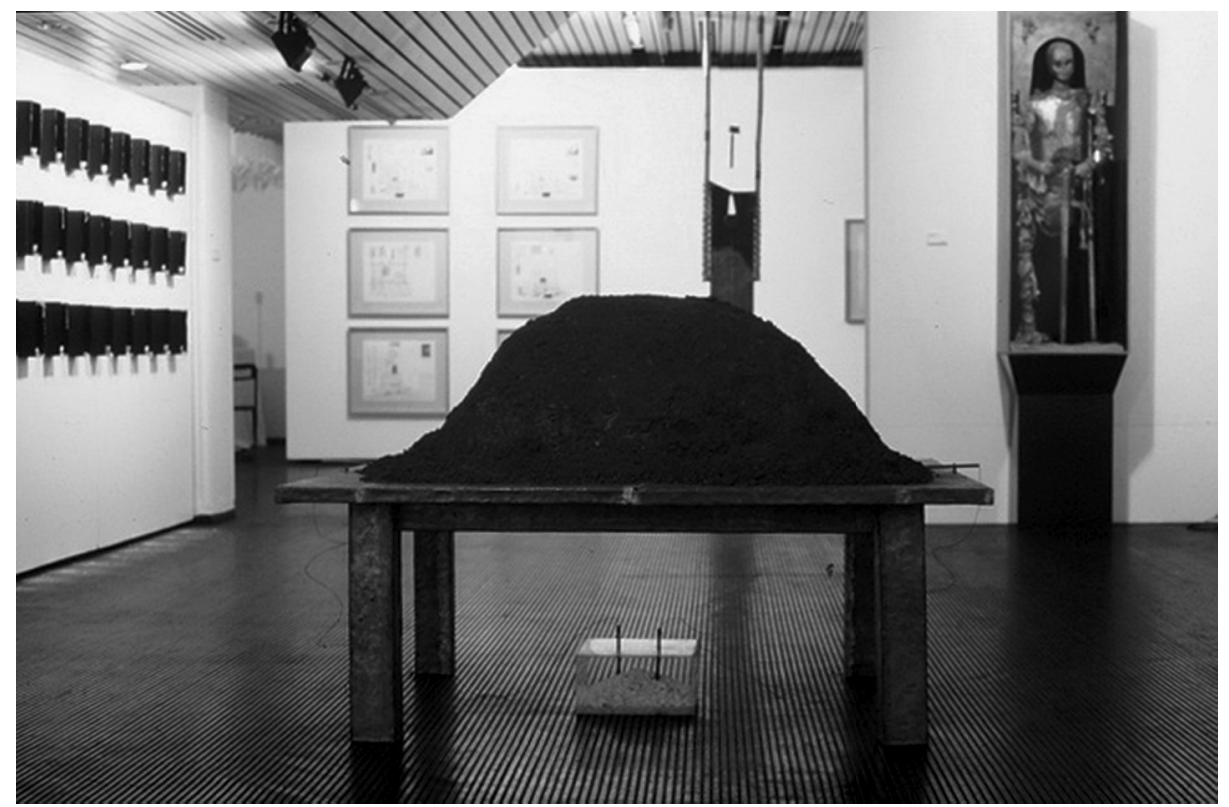

[Fig. 5. Alfredo Portillos, "Mesa energética", 1994.]

En la "Mesa Energética" presentada en la muestra "Veinte críticos eligen a veinte artistas"14 de 1994 en la Fundación Banco Patricios, retoma las reflexiones sobre la elaboración de energía de las papas -tubérculo de origen americano- que el artista Víctor Grippo realizara en la Serie de obras "Analogías" (1971). En esta ocasión, presentó una mesa recubierta de plomo que soportaba una pequeña montaña de tierra de la que parten dos electrodos que conducen la energía de la tierra a una caja acrílica con azufre y luego a un voltímetro. En la versión de Portillos no interesa la relación de la energía acumulada como en la obra de las analogías del tubérculo latinoamericano homologado al proceso de acumulación de conciencia social como sistema de arte. Sino, cómo el objeto ritual recupera cierta discursividad de las obras de los setenta, puesto que apela energéticamente a la tierra como materia sacra, que deja de lado cualquier lectura de un conceptualismo en clave científica, y obedece concretamente a la carga de energía vital, provocada en términos concretos, y a la

${ }^{14}$ Las otras dos obras exhibidas en dicha ocasión fueron De la misma sangre distinto color (video-instalación), y Mensaje a los del tercer milenio desde el vientre de la Pachamama (objeto), elegidas y prologadas en el catálogo por Rosa Brill. 
vez telúrica, dado que el montículo de tierra simboliza a la Pachamama (Madre Tierra).

Ofrendar y rogar a la madre tierra es un gesto y un acto del cual puede oficiarlo - de forma pragmática - toda persona que crea en la divinidad femenina, sin intermediarios, nomás que sean devotos como cualquier campesino, comadre, maestro o puestero de un pueblo o ciudad. Esta obra, reasume un horizonte simbólico que pone en tela de juicio la ensimismada mirada ciudadana, racional, descreída de las posibilidades potenciales de una naturaleza viva en relación con lo humano.

Estos elementos trazan dos factores estructurantes en el vocabulario estético del artista: la elaboración de un lenguaje formal a través de materiales que surgen al margen de cierto denominador común aceptable dentro de los parámetros de experimentación institucional. Y por otro lado, el carácter simbólico que enfatizan los elementos y las ofrendas por su modalidad pragmática y funcional como objetos de culto, muchos de ellos, extraídos de la realidad cotidiana y que forman parte del instrumental de mesas sagradas para su acción ritual.

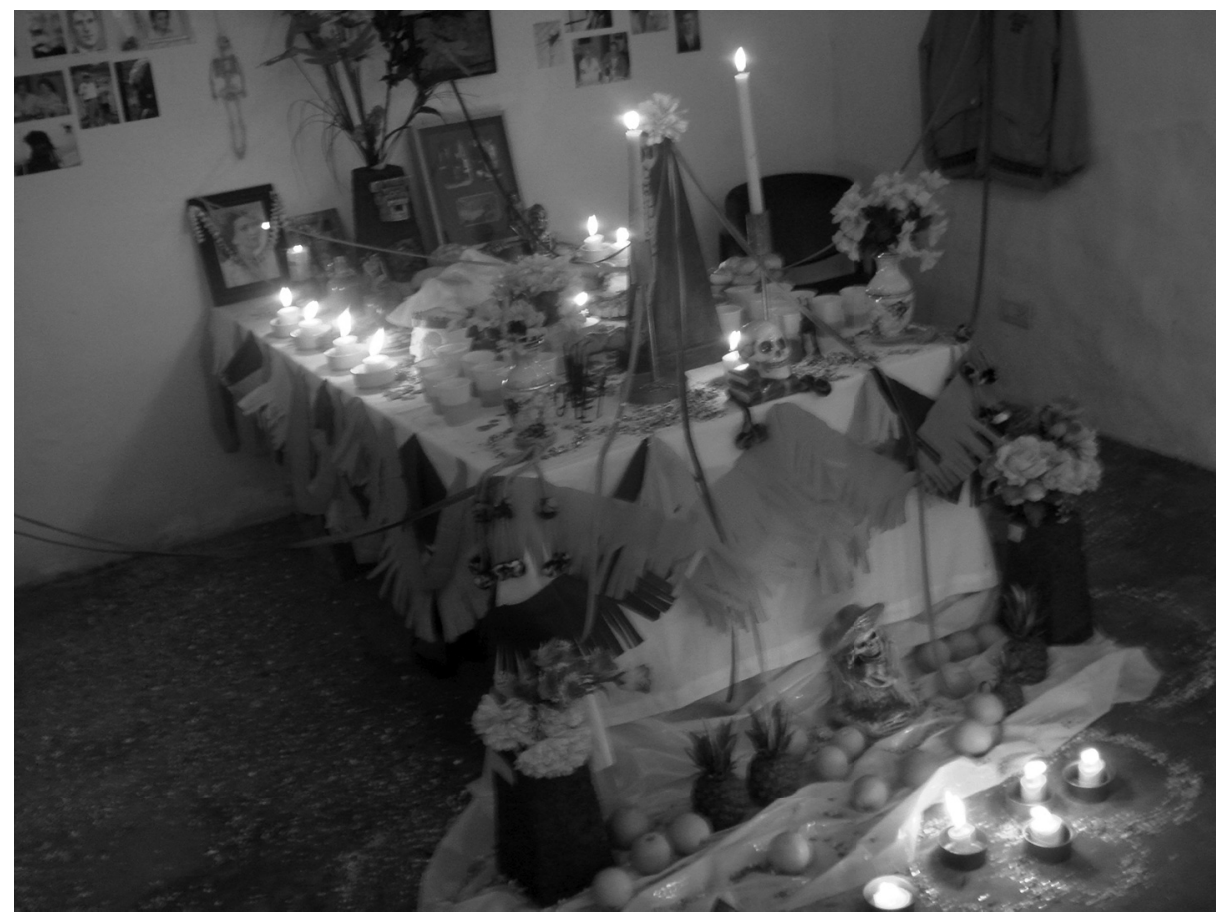

[Fig. 6. Alfredo Portillos, “Altar de Difuntos”, 2008.] 
Dicha marginalidad es la que recupera Portillos al colocar las cruces de cañas de forma torcida -o corrida-, en alusión a la diferenciación en los entierros colectivos forzados de los pueblos indígenas, como en el grupo cultural de los Quilmes, en cuanto al recurso visual utilizado por el conquistador para distinguir selectivamente un muerto común (Indio) de la sepultura del verdadero cristiano.

La intención de invertir y reponer un signo visual tradicional y dogmático como las cruces mortuorias, produce una rebeldía de los símbolos que sitúa la obra de Alfredo Portillos en un horizonte propio de sentido que sigue indagando -de manera incisiva- sobre las posibles maneras de pensar las identidades en América Latina.

La selección de una última pieza ritual nos lleva a analizar la experiencia del "Altar de Difuntos" realizado en el espacio cultural Barraca Vorticista en paralelo al trabajo de otros artistas para el 2 de noviembre de 2008.

Ese altar fue en conmemoración de la última compañera del artista, aunque contaba con imágenes y fotos de otros seres queridos. Allí el público podía compartir las imágenes que había llevado de sus muertos, las fotos, los muñequitos de pan, las frutas, el vino y la bebida para brindar por la memoria de nuestros muertos. En un momento de la noche, Portillos ofrendó unas palabras a los que todavía merodeaban ese otro tiempo entre los difuntos, y dijo: "los restos de comida y bebida me los llevo y hago otro ritual, porque esto ya no es arte, esto es otra cosa...".

La posibilidad de pensar esas "otras cosas" que desbordan los límites autonómicos del arte son las condiciones fundamentales que permiten vislumbrar que algún sentido de lo artístico vuelva a formar parte de la fragua de la vida. 


\section{BibliografíA}

ARIÈs 2007 [1975] - P. Ariès, Morir en Occidente. Desde la Edad Media hasta nuestros días, Buenos Aires 2007. [1975]

De SAnTis 2006 - D. De Santis, A vencer o morir. Historia del PRT-ERP documentos, t. I, Buenos Aires 2006.

D’Hondt 1974 - R. D’Hondt, "New Reform”, n.22, 1974.

García Canclini 2001 [1990] - N. García Canclini, Culturas Híbridas. Estrategias para entrar y salir de la modernidad, Buenos Aires 2001. [1990]

Mariátegui 1972 [1924] - J. C. Mariátegui, Ideología y Política Amauta, Lima 1972. [1924]

Santucho 1956 - F. R. Santucho, Dimensión Revista Bimestral de Cultura y Crítica, "América como conciencia", n.4 (1), 1956.

\section{Summary}

To ritualize death. Latin American identities in the conceptual practices of Alfredo Portillos

How to reinterpret Latin American identity discourses which were present in the artistic and political practices of the 1970s? How to revaluate their achievements and reinterpret them in the neo-liberal and globalized world of the 1990s, based on selected aesthetic propositions of an Argentinian artist, Alfredo Portillos? How are the emancipatory powers of such practices reactivating and functioning in the contemporary context? The proposed theoretical reflection on the artistic activity of Alfredo Portillos aims at reinterpreting the processes of circulation, valorisation and reception of some works which were omitted during creation of a historiographic account of "Grupo de los Trece" and then CAyC (Buenos Aires). The proposed reflections refer to different scopes of regional aesthetics in search for identity in Latin America and their connections with various political contexts. The narrative identity was accepted by the artist for the first time in 1973, when during the fourth edition of "Salón Premio Paolini", he presented a work showing an acrylic hermitage. A title of the work, which appeared in the catalogue of "Funerary urn of those who died for liberation of Latin America" (Urna funeraria de los caídos por la Liberación Latinoamericana), was very meaningful. This first semantic and conceptual proposition, including curiosity of matter characteristic of folk religiosity has become an element present in all the rituals presented by Alfredo Portillos (also in the latest one). 


\section{Streszczenie}

\section{Rytualizacja śmierci. Tożsamości Ameryki Lacińskiej w konceptualnych praktykach Alfredo Portillosa}

Jak na nowo zinterpretować latynoamerykańskie dyskursy tożsamościowe, które naznaczyły artystyczne i polityczne praktyki lat 70.? Jak ocenić na nowo ich osiągnięcia i zreinterpretować w neoliberalnym i zglobalizowanym świecie lat 90., opierając się na wybranych propozycjach estetycznych argentyńskiego artysty Alfredo Portillosa? W jaki sposób emancypacyjne moce takich praktyk reaktywują się i funkcjonują we współczesnym kontekście? Propozycja refleksji teoretycznej dotyczącej działalności artystycznej Alfredo Portillosa ma na celu reinterpretację procesów obiegu, waloryzacji i lektury niektórych prac pominiętych w czasie tworzenia relacji historiograficznej na temat „Grupo de los Trece”, a następnie CAyC (Buenos Aires). Proponowane przemyślenia odnoszą się do różnych zakresów estetyki regionalnej w poszukiwaniu tożsamości w Ameryce Łacińskiej i ich związków z różnymi kontekstami politycznymi.

Po raz pierwszy tożsamość narracyjna została przyjęta przez artystę w 1973 roku, kiedy podczas czwartej edycji „Salón Premio Paolini” zaprezentował dzieło ukazujące akrylową pustelnię. Bardzo wymowny był tytuł pracy, który pojawił się w katalogu „Urna pogrzebowa poległych na wyzwolenie Ameryki Łacińskiej" (Urna funeraria de los caidos por la Liberación Latinoamericana). Ta pierwsza propozycja semantyczno-pojęciowa, w której zawiera się osobliwość materii charakterystycznej dla religijności ludowej, stała się elementem obecnym we wszystkich rytuałach prezentowanych przez Alfredo Portillosa (także w ostatnim). 